\title{
MONITORING THE IMPACT OF HUMAN ACTIVITIES IN ADMIRALTY BAY, KING GEORGE ISLAND, ANTARCTICA: ISOTOPIC ANALYSIS OF C AND N IN THE SUMMER OF 2005/2006
}

http://dx.doi.org/10.4322/apa.2014.047

Thais Navajas Corbisier ${ }^{1}$, Sandra Bromberg ${ }^{1}$, Paula F. Gheller ${ }^{1}$, Francyne E. Piera ${ }^{1}$, Mônica A. Varella Petti ${ }^{1}$

1'Departmento de Oceanografia Biológica, Instituto Oceanográfico, Universidade de São Paulo - USP, São Paulo, SP, Brazil

*e-mail: tncorbis@usp.br

\begin{abstract}
Stable isotopic analyses have been used for assessing anthropogenic influence in marine communities. The variation of stable $C$ and $N$ isotope signatures in sources of organic matter and in benthic invertebrates were investigated at Martel Inlet nearshore zone, during the summer of 2005/2006, to attend a monitoring program. Water, sediment and invertebrates of different trophic types (suspensivore, depositivore, grazer and carnivore) were sampled at the intertidal and subtidal zones (up to $25 \mathrm{~m}$ ) off the Brazilian Antarctic Station Comandante Ferraz (CF) in two periods of the summer. As a reference area, Ullmann Point (UP) was sampled in the same way. Off CF, the $\delta^{13} \mathrm{C}$ values for consumers ranged from -23.92 (Laternula elliptica) to -12.34\%o (Nacella concinna) in Nov/2005, and from-23.36 to -12.73\%o (L. elliptica and Yoldia eightsi, respectively) in Feb/2006. Some ${ }^{13} \mathrm{C}$ values were more enriched in CF in February when compared to November, mostly for POM and sediment. This result was not observed in Ullmann Point and suggested an influence of the sewage organic matter in the coastal area near the Brazilian Station, mainly at the beginning of summer. The $\delta^{15} \mathrm{~N}$ values for sources and consumers did not differ significantly between areas or periods.
\end{abstract}

Keywords: stable isotopes, trophic interactions, benthic communities, nearshore zone

\section{Introduction}

Stable isotopes have been utilized to trace the transference of organic matter of different origins along the trophic webs (Peterson, 1999). The isotopic signatures in consumer tissues are, in general, related to the isotopic composition of their diet ("you are what you eat"), occurring an enrichment of heavy isotopes, e.g. of carbon $\left({ }^{13} \mathrm{C} /{ }^{12} \mathrm{C}\right)$ and nitrogen $\left({ }^{15} \mathrm{~N} /{ }^{14} \mathrm{~N}\right)$ around $1 \%$ and of $3-4 \%$, respectively, between the consumer and its food (Peterson \& Fry, 1987). The carbon and nitrogen ratios (expressed as $\delta^{13} \mathrm{C}$ and $\delta^{15} \mathrm{~N}$ ) are generally utilized to indicate the organic matter source and the $\delta^{15} \mathrm{~N}$ the trophic level, as well.
Eutrophication or increased load of organic matter in marine nearshore environments can be attributed to anthropogenic inputs of sewage effluents. Stable-carbon or stable-nitrogen isotope analysis are also becoming useful to identify the source, extent and the fate of biologically available sewage carbon and nitrogen (Peterson, 1999; Costanzo et al., 2001; Waldron et al., 2001; Gartner et al., 2002; Rogers, 2003). Scientific and logistic activities in Antarctica have introduced anthropogenic compounds in otherwise pristine areas (Martins et al., 2005). Sewage isotopic signatures of $\mathrm{C}$ or $\mathrm{N}$ have already being detected 


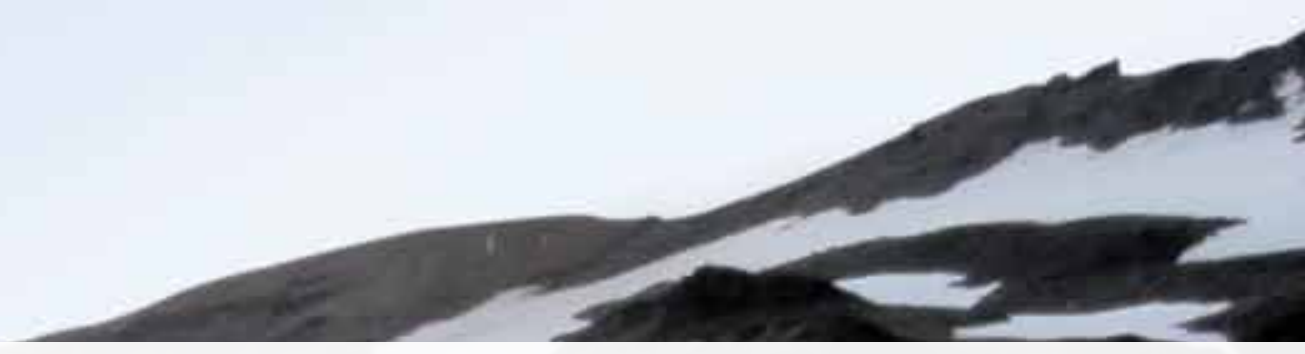

in sediment and in some benthic organisms near McMurdo Station (Conlan et al., 2006).

The influence of sewage and of the aliphatic hydrocarbons (AHs) and polycyclic aromatic hydrocarbons was observed only near the sewage outfall close to the Brazilian station (CF). Their presence was detected within a distance of $200 \mathrm{~m}$ in the water column and of $400 \mathrm{~m}$ (human sterols) and $700 \mathrm{~m}$ (hydrocarbons) in the sediment. Nonetheless, the dispersion of the sewage plume in the shallow coastal zone of Martel Inlet is favoured by the hydrodynamics, mainly influenced by the tides. As a result, the contamination in Admiralty Bay is assumed to be punctual and restricted to the proximities of $\mathrm{CF}$, especially concerning the sewage outlet (Martins et al., 2005; Bícego et al., 2009).

We analyzed the variation in the isotopic signature of benthic communities to verify if there was anthropogenic influence off the Antarctic Brazilian Station (sewage and hydrocarbons), in Martel Inlet during the summer of

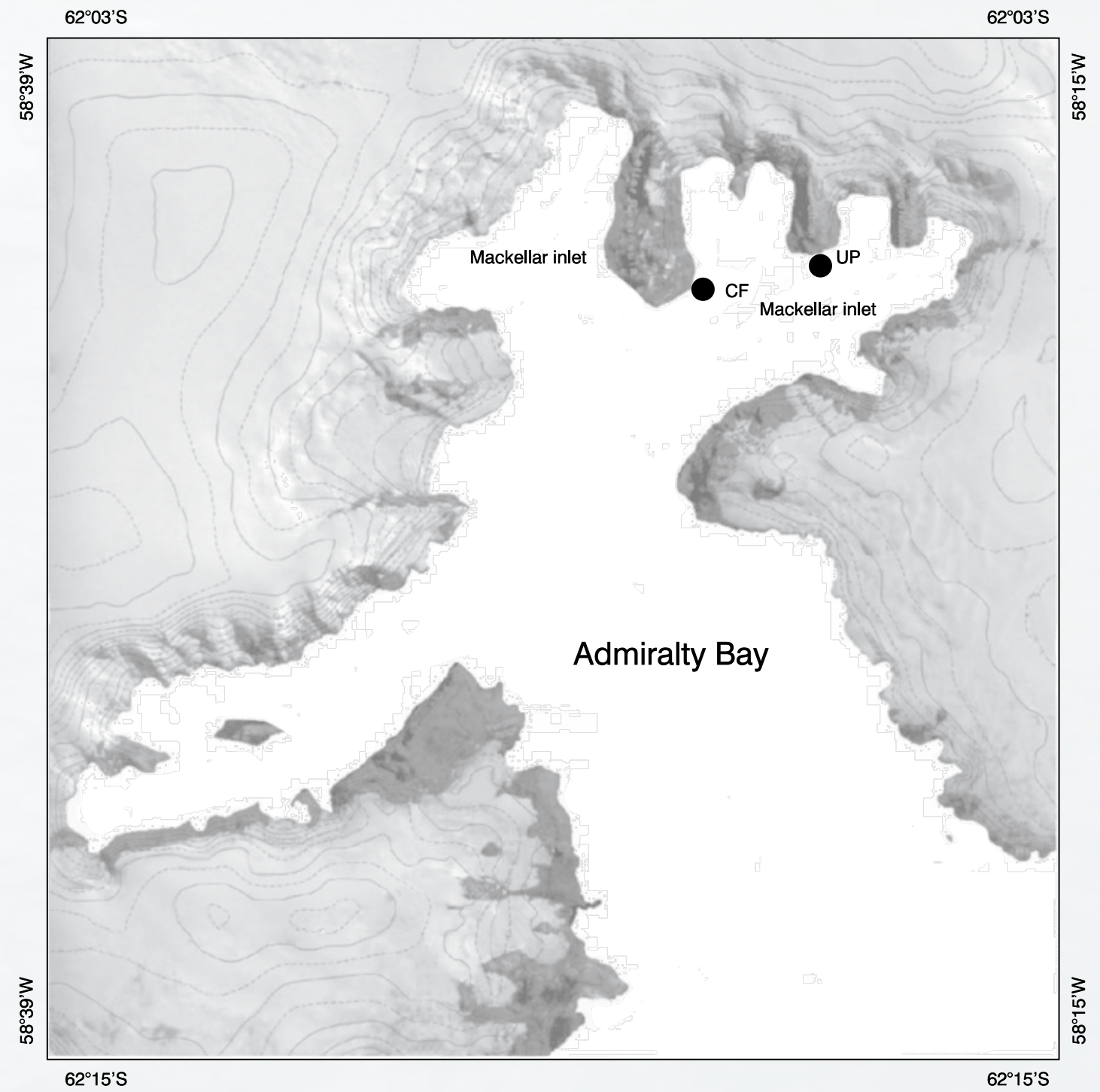

Figure 1. Admiralty Bay and the sampling areas. 

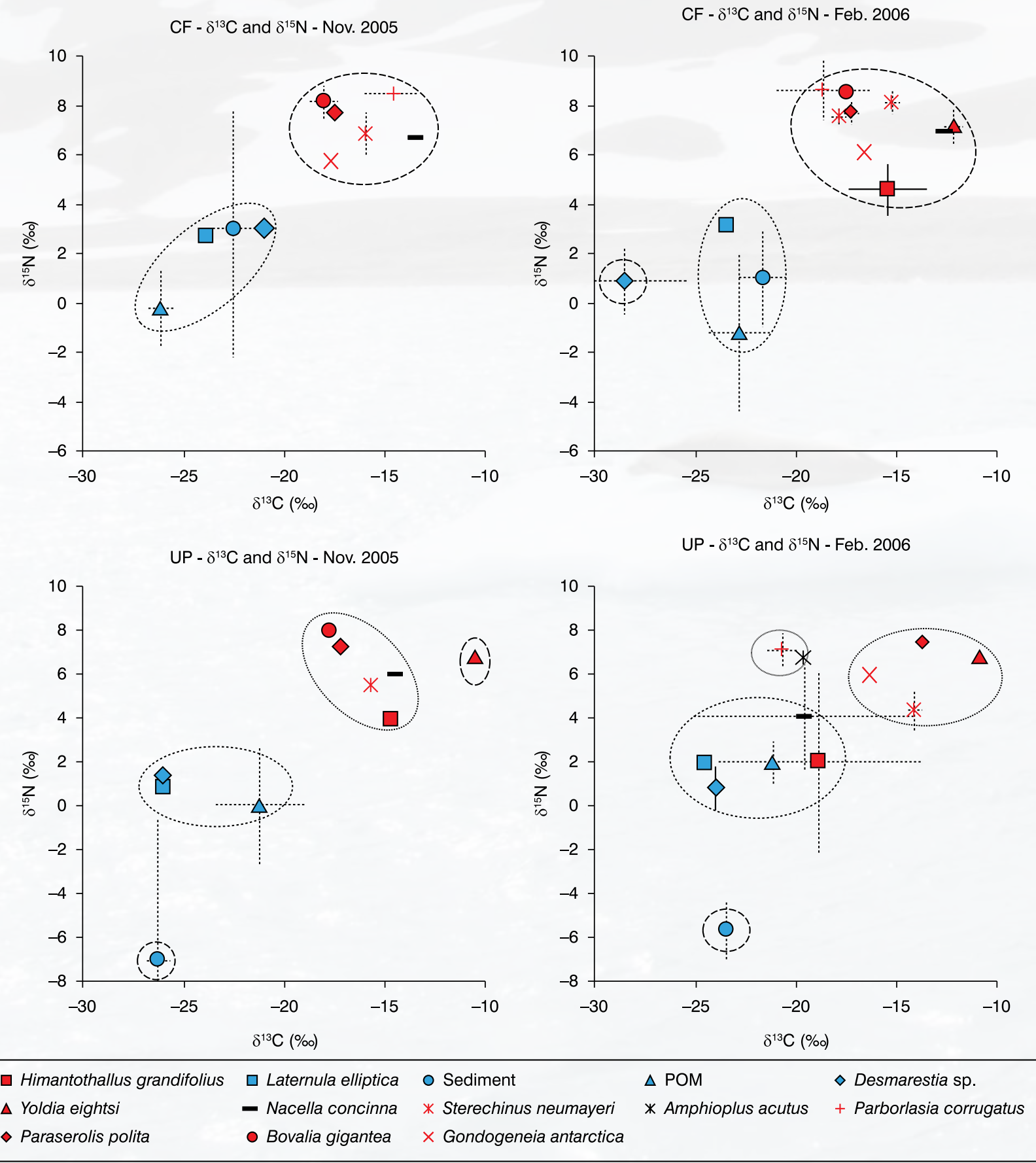

\begin{tabular}{|lllll|}
\hline$\square$ Himantothallus grandifolius & $\square$ Laternula elliptica & $\circ$ Sediment & $\Delta$ POM & $\diamond$ Desmarestia sp. \\
$\Delta$ Yoldia eightsi & - Nacella concinna & $*$ Sterechinus neumayeri & $*$ Amphioplus acutus & + Parborlasia corrugatus \\
$\diamond$ Paraserolis polita & $\circ$ Bovalia gigantea & $\times$ Gondogeneia antarctica & & \\
\hline
\end{tabular}

Figure 2. Dispersion graphics for $\delta^{13} \mathrm{C}$ and $\delta^{15} \mathrm{~N}$ values (mean $\pm \mathrm{sd}$ ) for sources and consumers at $\mathrm{CF}$ and UP in two summer periods (2005/2006). 
2005/2006. This study was part of the Network 2 program (Weber \& Montone, 2006). Previous trophic web studies using stable isotopes were undertaken in this area in the summer of 1996/1997 (Corbisier et al., 2004) and in three other areas in Admiralty Bay in 2003 (Corbisier at al., personal communication).

\section{Material and Methods}

Water, sediment and invertebrates of different trophic types (suspensivore, depositivore, grazer and carnivore) were sampled in the intertidal and subtidal zones (up to $25 \mathrm{~m}$ ) off the Brazilian Station Comandante Ferraz (CF), under the sewage outfall influence area, at the beginning (Nov/2005) and at the end of the summer (Feb/2006). As a reference area, Ullmann Point (UP) was sampled in the same way (Figure 1).

Samples of benthic invertebrates, macroalgae, and sediments were obtained manually in the intertidal zone and on board of the R/B SKUA, using a van Veen grab, a dredge, or by Scuba diving. Surface water samples for suspended particulate organic matter (POM) analysis were obtained with bottles. Methods followed those of a previous study with the addition of the $\delta^{15} \mathrm{~N}$ analysis (Corbisier et al., 2004). The stable isotope measurements were performed by the Stable Isotope Facility of the Department of Agronomy and Range Science, Davis, California, U.S., using a Europa Hydra 20/20 isotope ratio mass spectrometer. Stable isotope ratios are expressed in $\delta$ notation as part per thousand (\%o) according to the following relationship:

$$
\delta \mathrm{X}=\left[\left(\mathrm{R}_{\text {sample }} / \mathrm{R}_{\text {standard }}\right)-1\right] \times 10^{3}
$$

where $\mathrm{X}={ }^{13} \mathrm{C}$ or ${ }^{15} \mathrm{~N}$, and $\mathrm{R}={ }^{13} \mathrm{C} /{ }^{12} \mathrm{C}$ or ${ }^{15} \mathrm{~N} /{ }^{14} \mathrm{~N}$ (Peterson \& Fry, 1987). The standard reference for carbon is Pee Dee Belemnite (PDB) and atmospheric $\mathrm{N}_{2}$ for nitrogen.

A cluster analysis (Euclidean Distance, average grouping method) was carried out on $\delta^{13} \mathrm{C}$ and $\delta^{15} \mathrm{~N}$ mean values of sources and consumers (normalized data) in order to identify similar groups (Primer v6). Significant differences were searched using the Kruskall-Wallis test $(p<0.05)$.

\section{Results}

\section{Brazilian Station - CF}

In Nov/2005, $\delta^{13} \mathrm{C}$ mean values varied from -26.52 to $-25.91 \%$ for POM, from -29.27 to $-20.87 \%$ o for sediment, $-21.01 \%$ was the value for the algae Desmarestia sp., and for consumers they ranged from -23.92 (suspensivore bivalve Laternula elliptica) to $-13.49 \%$ (grazer gastropod Nacella concinna) (Figure 2). In Feb/2006, $\delta^{13} \mathrm{C}$ mean values for POM were more enriched and ranged from -23.69 to $-20.59 \%$, for sediment from -22.09 to $-20.56 \%$, for macroalgae from -28.33 to $-14.13 \%$, and for consumers from -23.36 to $-12.34 \%$ (L. elliptica and the depositivore bivalve Yoldia eightsi, respectively) (Figure 2).

The $\delta^{15} \mathrm{~N}$ mean values for POM in Nov/2005 were close to $0 \%$ ( -1.05 and $0.68 \%$ ), whereas for sediment they varied between 0.32 and $4.71 \%$. The highest value was found in front of the sewage outfall. For Desmarestia sp. values varied around 3.00\% and for consumers they varied from 2.73 (L. elliptica) to 8.69\%o (carnivore amphipod Bovalia gigantea) (Figure 2). In Feb/2006, the POM $\delta^{15} \mathrm{~N}$ values were also low (-4.21 to $1.94 \%$ ); for sediment the $\delta^{15} \mathrm{~N}$ values ranged from 0.21 to $1.84 \%$, for algae between 1.07 and $5.32 \%$, and from 3.31 (L. elliptica) to $8.77 \%$ (carnivore ribbon worm Parborlasia corrugatus) for consumers (Figure 2).

The producers and the suspensivore L. elliptica formed a group and the other consumers formed a second group in which there is no difference between feeding types (Figure 2).

The comparison of the $\delta^{13} \mathrm{C}$ data from Nov/2005 with those from $\mathrm{Feb} / 2006$ suggests an enrichment of $\delta^{13} \mathrm{C}$ values in the last period. This enrichment was more notable in the POM $(p<0.05)$ and sediment (although non significant) (Figure 3a). A very small variation of $\delta^{15} \mathrm{~N}$ values was noted between the two periods, being a little more enriched at the end of the summer for POM, sediment, and four consumers; nevertheless, these differences were not significant $(p<0,05)$. 


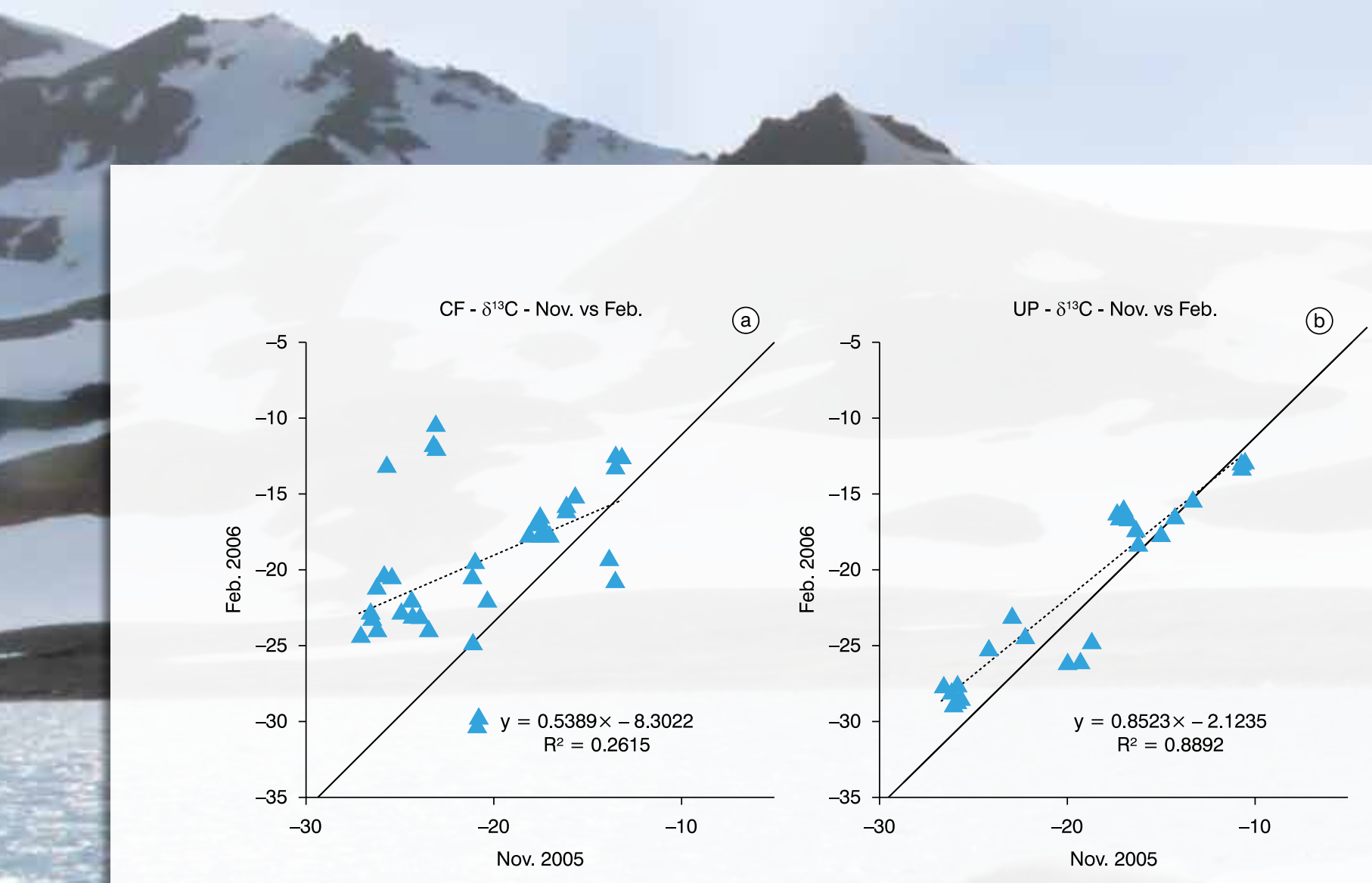

Figure 3. Linear regression for $\delta^{13} \mathrm{C}$ data from Nov/2005 in comparison with those from the Feb/2006 for both areas: a-CF and b-UP.

\section{Ullmann Point - UP}

In Ullmann Point, in Nov/2005, POM $\delta^{13} \mathrm{C}$ mean values ranged from -23.12 to $-19.40 \%$; for sediment the value was $-26.18 \%$, and for macroalgae the range was from -14.93 to $-25.94 \%$. Consumers had $\delta^{13} \mathrm{C}$ values between -25.89 (L. elliptica) and $-10.81 \%$ (Y. eightsi) (Figure 2). In $\mathrm{Feb} / 2006, \delta^{13} \mathrm{C}$ values for POM varied between -22.13 and $-20.97 \%$, for sediment the mean value was $-23.73 \%$, and for algae the values ranged from -24.27 to $-15.04 \%$. The $\delta^{13} \mathrm{C}$ values for consumers varied from -24.74 (L. elliptica) and $-11.73 \%$ (Y. eightsi) (Figure 2).

Regarding $\delta^{15} \mathrm{~N}$, in Nov/2005, POM values ranged from -0.81 to $4.22 \%$; for sediment $\delta^{15} \mathrm{~N}$ value was $-3.03 \%$, for macroalgae it varied from 2.56 to $4.22 \%$, and for consumers, from 1.93 (L. elliptica) to $8.36 \%$ (B. gigantea) (Figure 2). In Feb/2006, $\delta^{15} \mathrm{~N}$ values for POM varied between 1.16 and $3.67 \%$, the sediment mean value was very low $(-5 \%)$, for algae $\delta^{15} \mathrm{~N}$ values ranged from -1.32 to $6.20 \%$, and for consumers, from 2.31 (L. elliptica) and 7.95\%o (the isopod Paraserolis polita) (Figure 2).

As occurred in CF, L. elliptica formed a group with the producers, but the sediment was separated, and the consumers formed two different groups that were distinct in the two periods of the summer (Figure 2).

The comparison of the data from Nov/2005 with those from Feb/2006 does not suggest a difference in the $\delta^{13} \mathrm{C}$ values (Figure $3 \mathrm{~b}$ ). Considering the $\delta^{15} \mathrm{~N}$, the values had a small enrichment in Feb/2006 in four subtidal components (not statistically significant).

\section{Discussion}

In front of the Brazilian station (CF), the $\delta^{13} \mathrm{C}$ values were less enriched for some components of the community than in UP (Figure 2), which could suggest a contribution of organic matter originated from sewage that has usually low $\delta^{13} \mathrm{C}$ (Peterson, 1999; Waldron et al., 2001; Rogers, 2003; Conlan et al., 2006). The $\delta^{15} \mathrm{~N}$ values for sediment, more enriched in the area under the sewage influence, can be related to a higher ammonia concentration of anthropogenic origin (Peterson, 1999; Waldron et al., 2001; Conlan et al., 2006). The clustering of different feeding types in a same group in CF is also an indication of sources of organic matter with more similar signature. 
The differences between the two summer periods in CF did not suggest an increase of the sewage influence towards the end of summer, mainly for the $\delta^{13} \mathrm{C}$ results.

In the summer of $2010 / 11$ a new sampling will be undertaken aiming the continuous monitoring of Admiralty Bay in the scope of the INCT-APA program. For a better understanding of the anthropogenic influence, the isotopic signatures of more areas, periods and different organisms need to be analyzed in Admiralty Bay. Samples from the sewage are also necessary to compare with the obtained results.

\section{Acknowledgements}

Financial support from Network 2 Project (CNPq process 550354/2002-6) and Instituto Nacional de Ciência e Tecnologia Antártico de Pesquisas Ambientais (CNPq process 574018/2008-5 and FAPERJ process E-26/170.023/2008), Ministério do Meio Ambiente (MMA), Ministério de Ciência e Tecnologia (MCT) and Comissão Interministerial para Recursos do Mar (CIRM).

\section{References}

Bícego, M.C.; Zanardi-Lamardo, E.; Taniguchi, S.; Martins, C.C.; Silva, D.A.M. \& Sasaki, S.T.; Albergaria-Barbosa, A.C.R.; Paolo, F.S.; Weber, R.R. \& Montone, R.C. (2009). Results from a 15-year study on hydrocarbon concentrations in water and sediment from Admiralty Bay, King George Island, Antarctica. Antarctic Science, 21(3): 209-20.

Conlan, K.E., Rau, G.H., Kvitek, R.G. (2006). $\delta^{13} \mathrm{C}$ and ${ }^{15} \mathrm{~N}$ shifts in benthic invertebrates exposed to sewage from McMurdo Station, Antarctica. Marine Pollution Bulletin, 52(12): 1695-1707.

Corbisier, T.N., Petti, M.A.V., Skowronski, R.S.P., Brito, T.A.S. (2004). Trophic relationships in the nearshore zone of Martel Inlet (King George Island, Antarctica): $\delta^{13} \mathrm{C}$ stable isotope analysis. Polar Biology, 27(2): 75-82.

Costanzo, S.D., O'Donohue, M.J., Dennison, W.C., Loneragan, N.R., Thomas, M. (2001). A new approach for detecting and mapping sewage impacts. Marine Pollution Bulletin, 42(2): 149-156.

Gartner, A.; Lavery, P.; Smit, A.J. (2002). Use of $\delta^{15} \mathrm{~N}$ signatures of different functional forms of macroalgae and filter-feeders to reveal temporal and spatial patterns in sewage dispersal. Marine Ecology Progress Series, 235: 63-73.

Martins, C.C.; Montone, R.C.; Gamba, R.C. \& Pellizari, V.H. (2005). Sterols and fecal indicator microorganisms in sediments from Admiralty Bay, Antarctica. Brazilian Journal of Oceanography, 53(1-2): 1-12.

Peterson, B.J. (1999). Stable isotopes as tracers of organic matter input and transfer in benthic food webs: A review. Acta Oceanologica, 20(4): 479-487

Peterson, B.J. \& Fry, B. (1987). Stable isotopes in ecosystem studies. Annual Revierw of Ecology and Systematics, 18: $293-320$.

Rogers, K.M. (2003). Stable carbon and nitrogen isotope signatures indicate recovery of marine biota from sewage pollution at Moa Point, New Zealand. Marine Pollution Bulletin, 46(7): 821-827.

Waldron, S.; Tatner, P.; Jack, I. \& Arnott, C. (2001). The impact of sewage discharge in a marine embayment: a stable isotope reconnaissance. Estuarine, Coastal and Shelf Science, 52(1): 111-115.

Weber, R. R. \& Montone, R. C. (Coord.) (2006). Rede-2: Gerenciamento ambiental na Baía do Almirantado, Ilha Rei George, Antártica. Relatório final. Ministério do Meio Ambiente/ CNPq/SeCIRM/Proantar, Brasil. 255 p. 